\title{
How the techniques of molecular biology are developed from natural systems
}

\author{
Isobel Ronai \\ isobel.ronai@sydney.edu.au \\ School of Life and Environmental Sciences, The University of Sydney, Sydney, NSW, Australia.
}

\begin{abstract}
A striking characteristic of the highly successful techniques in molecular biology is that they are derived from natural systems. RNA interference (RNAi), for example, utilises a mechanism that evolved in eukaryotes to destroy foreign nucleic acid. Other examples include restriction enzymes, the polymerase chain reaction, green fluorescent protein and CRISPR-Cas. I propose that biologists exploit natural molecular mechanisms for their effectors' (protein or nucleic acid) activity and biological specificity (protein or nucleic acid can cause precise reactions). I also show that the developmental trajectory of novel techniques in molecular biology, such as RNAi, is four characteristic phases. The first phase is discovery of a biological phenomenon, typically as curiosity driven research. The second is identification of the mechanism's trigger(s), the effector and biological specificity. The third is the application of the technique. The final phase is the maturation and refinement of the molecular biology technique. The development of new molecular biology techniques from nature is crucial for biological research. These techniques transform scientific knowledge and generate new knowledge.
\end{abstract}

Keywords: mechanism; experiment; specificity; scientific practice; PCR; GFP. 


\section{Introduction}

Molecular biology is principally concerned with explaining the complex molecular phenomena underlying living processes by identifying the mechanisms that produce such processes (Tabery et al. 2015). In order to access the causal structure of molecular mechanisms it is generally necessary to manipulate the components of the mechanism and to observe the resulting effects with sophisticated molecular techniques. These techniques generate knowledge that cannot be obtained by any other means. Therefore, scientific knowledge in molecular biology advances in a distinctive way: progress is driven by the introduction and use of novel techniques. However, what drives the development of molecular biology techniques?

In this paper, I firstly provide evidence that highly successful molecular biology techniques are derived from natural systems. In Section 2, I explain how the natural systems' strategy for technique development means that the techniques utilise the activity of a mechanism's effector (protein or RNA) and exploit biological specificity (protein or nucleic acid can cause precise reactions). In Section 3, I present RNA interference (RNAi) as an exemplar case study to describe how molecular biology techniques are typically developed from nature. In Section 4, I show that molecular biology technique development can be divided into four phases. I conclude by discussing the implications of deriving techniques from nature for molecular biology.

\section{1) From natural systems to techniques}

A striking feature of the development of molecular biology techniques, which biologists themselves often highlight (for example, Lander 2016; Mello and Conte 2004), is that they are derived from natural systems. These techniques are not developed through rational design. In this paper I identify eight highly successful techniques of molecular biology that are derived from natural systems. In chronological order these are: restriction enzymes; DNA sequencing, polymerase chain reaction (PCR); gene targeting; green fluorescent protein (GFP); RNAi; induced pluripotent stem cells (iPS); and clustered regularly interspaced short palindromic repeats-CRISPR associated (CRISPR-Cas) (see Table 1). Throughout this paper I draw on RNAi as my detailed case study due to my firsthand experience with this technique (Ronai et al. 2016). RNAi is a technique that introduces molecules of RNA into an organism in order to reduce the expression of a gene of interest (reviewed in, Mello and Conte 2004) (Figure 1). The eight molecular biology techniques are so ubiquitous that they are regarded as common knowledge by biologists. So when these techniques are mentioned in the Methods section of a scientific article, a citation to the technique is often not necessary (for example, Ronai et al. 2016).

The eight molecular biology techniques discussed are derived from mechanisms that each evolved for a particular biological function in a natural system (see Table 1). The biological function of the RNAi mechanism, for example, is an organismal defence system for the destruction of foreign nucleic acid and mobile elements (van Rij and Andino 2006; Waterhouse et al. 1998; Waterhouse et al. 2001). Interestingly, the RNAi mechanism is thought to have been co-opted (Cerutti and Casas-Mollano 2006) for the precise regulation of endogenous gene expression, in particular for the regulation of developmental genes (Carrington and Ambros 2003). Therefore, the RNAi mechanism is a deeply entrenched process in eukaryotic organisms. The same biological function, to destroy foreign nucleic acid in the organism, underlies the techniques of RNAi (derived from eukaryotes) and CRISPR-Cas (derived from prokaryotes) (Bhaya et al. 2011; Wright et al. 2016), but the two techniques involve different molecular mechanisms (Table 1). Therefore, the 'arms race' that occurs between viruses and their organismal hosts has provided biologists with the basis of two techniques. In contrast the 


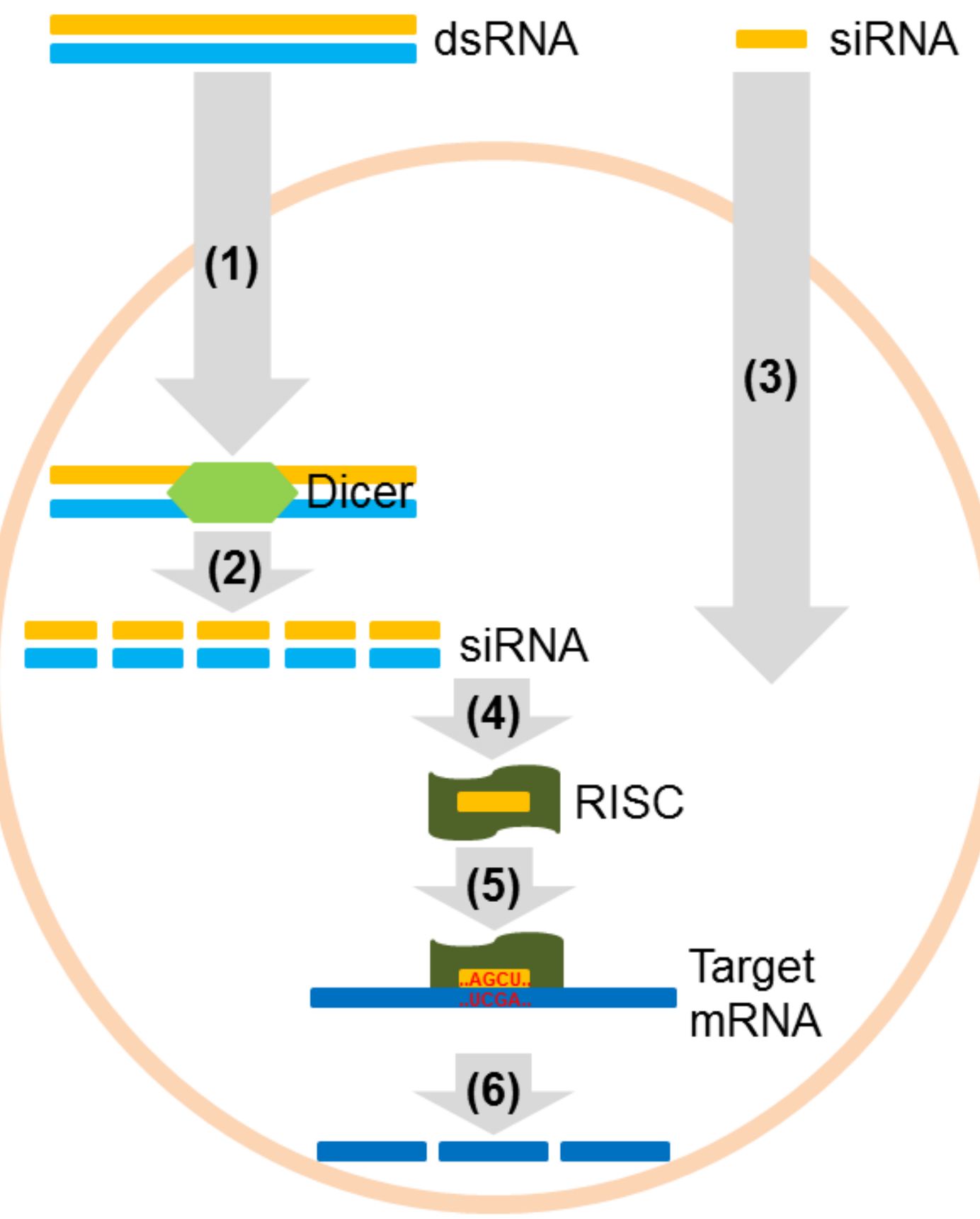

Fig. 1: A model of the molecular biology technique of RNA interference (RNAi). (1) Doublestranded RNA (dsRNA) is introduced into the experimental system. (2) The endogenous endonuclease Dicer cleaves the dsRNA into small fragments known as small interfering RNA (siRNA). (3) Or the siRNA is added directly into the experimental system. (4) The siRNA antisense strand attaches to the endogenous RNA-induced silencing complex (RISC), (5) which binds sequence specifically to the target mRNA. (6) RISC cuts the target mRNA which causes it to be degraded, therefore no gene function is executed. 
Table 1: Summary and characterisation of eight pivotal molecular biology techniques. These techniques are all derived from natural systems and are now utilised as methodologies. For key references see Table 2 .

\begin{tabular}{|c|c|c|c|c|c|}
\hline $\begin{array}{l}\text { Technique (in } \\
\text { chronological } \\
\text { order of } \\
\text { development) }\end{array}$ & $\begin{array}{l}\text { Originating } \\
\text { natural } \\
\text { system }\end{array}$ & $\begin{array}{l}\text { Biological } \\
\text { function of } \\
\text { mechanism }\end{array}$ & $\begin{array}{l}\text { Experimental } \\
\text { context }\end{array}$ & Type of effector & $\begin{array}{l}\text { Type of biological } \\
\text { specificity }\end{array}$ \\
\hline $\begin{array}{l}\text { 1. Restriction } \\
\text { enzymes }\end{array}$ & Bacteria & $\begin{array}{l}\text { Destroy foreign } \\
\text { nucleic acid from } \\
\text { bacteriophages }\end{array}$ & In vitro & $\begin{array}{l}\text { Restriction } \\
\text { endonuclease }\end{array}$ & $\begin{array}{l}\text { Stereochemical: DNA } \\
\text { recognition sequence }\end{array}$ \\
\hline $\begin{array}{l}\text { 2. DNA } \\
\text { sequencing }\end{array}$ & Bacteria & DNA replication & In vitro & DNA polymerase I & $\begin{array}{l}\text { Informational: } \\
\text { dideoxynucleotides (also } \\
\text { DNA primer) has } \\
\text { sequence match to DNA } \\
\text { template }\end{array}$ \\
\hline 3. PCR & Bacteria & DNA replication & In vitro & DNA polymerase I & $\begin{array}{l}\text { Informational: DNA } \\
\text { primers has sequence } \\
\text { match to DNA template }\end{array}$ \\
\hline $\begin{array}{l}\text { 4. Gene } \\
\text { targeting }\end{array}$ & $\begin{array}{l}\text { Organism or } \\
\text { cell culture }\end{array}$ & $\begin{array}{l}\text { Homologous } \\
\text { recombination }\end{array}$ & $\begin{array}{l}\text { Organisms \& } \\
\text { cell culture }\end{array}$ & $\begin{array}{l}\text { Endogenous } \\
\text { endonuclease (for } \\
\text { example, SPO11) }\end{array}$ & $\begin{array}{l}\text { Informational: } \\
\text { exogenous DNA has } \\
\text { sequence match to target } \\
\text { DNA/gene }\end{array}$ \\
\hline 5. GFP & Jellyfish & $\begin{array}{l}\text { Unknown - } \\
\text { emitted when } \\
\text { jellyfish is agitated } \\
\text { (Davenport and } \\
\text { Nicol 1955) }\end{array}$ & $\begin{array}{l}\text { Organisms \& } \\
\text { cell culture }\end{array}$ & $\begin{array}{l}\text { Green fluorescent } \\
\text { protein (GFP), in } \\
\text { particular the } \\
\text { flurophore }\end{array}$ & $\begin{array}{l}\text { Engineered } \\
\text { informational specificity: } \\
\text { GFP DNA placed in } \\
\text { specific location }\end{array}$ \\
\hline 6. RNAi & $\begin{array}{l}\text { Eukaryote or } \\
\text { cell culture }\end{array}$ & $\begin{array}{l}\text { Destroy foreign } \\
\text { nucleic acid or } \\
\text { gene regulation }\end{array}$ & $\begin{array}{l}\text { Eukaryote } \\
\text { organisms \& } \\
\text { cell culture }\end{array}$ & $\begin{array}{l}\text { Endogenous RNA- } \\
\text { induced silencing } \\
\text { complex (RISC), in } \\
\text { particular the } \\
\text { Argonaute } \\
\text { endonuclease }\end{array}$ & $\begin{array}{l}\text { Informational: dsRNA } \\
\text { ( \& siRNA) with } \\
\text { sequence match to target } \\
\text { mRNA }\end{array}$ \\
\hline 7. iPS & $\begin{array}{l}\text { Embryonic } \\
\text { stem cells }\end{array}$ & $\begin{array}{l}\text { Stem cell function } \\
\text { (unlimited self- } \\
\text { renewal \& } \\
\text { pluripotency) }\end{array}$ & Cell culture & $\begin{array}{l}\text { Transcription } \\
\text { factors (Oct4, Sox } 2 \\
c M y c \text { \& Klf4) }\end{array}$ & $\begin{array}{l}\text { Stereochemical: DNA } \\
\text { binding site }\end{array}$ \\
\hline 8. CRISPR-Cas & Bacteria & $\begin{array}{l}\text { Destroy foreign } \\
\text { nucleic acid from } \\
\text { bacteriophages }\end{array}$ & $\begin{array}{l}\text { Organisms \& } \\
\text { cell culture }\end{array}$ & $\begin{array}{l}\text { RNA-guided DNA } \\
\text { endonuclease (cas9) }\end{array}$ & $\begin{array}{l}\text { Informational: guide } \\
\text { RNA (crRNA + } \\
\text { tracrRNA) with } \\
\text { sequence match to target } \\
\text { DNA }\end{array}$ \\
\hline
\end{tabular}


technique of GFP is derived from a relatively unique biological phenomenon in jellyfish and is therefore taxonomically restricted.

As is usual in biological research practice, when a molecular biology technique is developed for an organismal experimental context (Table 1) it is first tested in a 'model organism' system. Model organisms provide standardised experimental systems that are relatively well characterised at the molecular level act as a prototype for technique development (Ankeny 2000). This is particularly important given the complexity and cost of molecular biology experiments. The expectation is that, due to the fundamental unity of living systems, if a technique is validated in a model organism, then it will be possible to apply it to other organisms. For example, RNAi was first developed using the model organism Caenorhabditis elegans (Fire et al. 1998).

The explanatory focus of biology is what occurs in nature so experiments must be compatible with living processes (Weber forthcoming) rather than create artificial phenomena. Therefore, the use of pre-existing, natural mechanisms for technique development in molecular biology is advantageous. These techniques are compatible with other biological processes and able to operate within a cellular context. Furthermore, the use of a natural mechanism may allow the continuing function of the biological process (for example, GFP) and cellular based techniques can be stably inherited in designed constructs with transgenerational effects. These techniques can be used to observe or intervene in active, complex biological processes even when no comprehensive understanding of these processes exists.

\section{2) The importance of natural systems for the development of techniques in molecular biology}

In this section I analyse why natural systems are used for the development of techniques in molecular biology. Natural mechanisms have been selected and optimised by evolution. These mechanisms therefore have a high level of validation. Molecular biology techniques exploit two characteristics of natural mechanisms: an effector's activity and the use of biological specificity.

\section{1) Effector activity}

Living systems use effectors (such as, proteins or RNAs) to generate a particular activity within a mechanism. I have identified the protein effector, all from a natural system, for each of my eight molecular biology techniques (Table 1). The majority of the techniques utilise proteins that are catalytic enzymes (note, enzyme names normally end with '-ase') and the techniques leverage the efficiency of the enzymatic activity (Table 1). The two exceptions are the techniques of GFP and iPS which utilise a protein's stereochemistry, a flurophore or structural motif, respectively (Table 1).

The technique's effector is either endogenous or exogenous to the experimental system (Table 1). Endogenous based techniques use the effector for its original purpose but they co-opt the overall mechanism. Whereas, exogenous based techniques use the effector for its original purpose but in another biological context, so the effector needs to be introduced into the experimental system. For example, the effector of RNAi is the RNA-induced silencing complex (RISC), which is an endogenous component of a molecular mechanism present in all eukaryotes and involves an enzyme (Cerutti and Casas-Mollano 2006). RISC cuts the target mRNA and cause it to be degraded (Hammond et al. 2000; Martinez et al. 2002). 


\section{2) Biological specificity}

Living systems need biological specificity to achieve fine-grained control over their molecular mechanisms (Griffiths et al. 2015; Waters 2007; Woodward 2010). Biologists artificially introduce biological specificity into their experimental systems. The eight molecular biology techniques studied here utilise this biological specificity to precisely access the target mechanism with minimal off-target events. Drawing on this specificity means that the technique can be multiplexed (multiple nucleic acid sites targeted at the same time). I have identified that the majority of the eight molecular biology techniques use nucleic acid sequence informational specificity (Griffiths and Stotz 2013), nucleic acid is the substrate of the mechanism (Table 1). For example, RNAi uses nucleic acid specificity when double-stranded RNA (dsRNA) or small interfering RNA (siRNA) is introduced into the experimental system and binds sequence specifically to the target mRNA. One molecular biology technique (GFP) uses what I have termed 'engineered informational specificity', where the biologist creates the specificity by placing the effector in a highly specific location. Two other molecular biology techniques, iPS and restriction enzymes, use protein stereochemical specificity (Griffiths and Stotz 2013) (Table 1).

For nucleic acid guided techniques the informational specificity is artificially designed whereas stereochemical specificity uses natural specificity. Therefore, stereochemical specificity is fixed before the start of the experiment and is less programmable than informational specificity.

Before RNAi was developed as a technique only a non-specific, permanent disruption in gene expression via mutagenesis was possible (Bellés 2010). In contrast, RNAi provides more finegrained control because it uses nucleic acid sequence informational specificity. A biologist introduces RNA molecules into the experimental system which initiates the mechanism and its nucleotide sequence specifies the mRNA sequence to degrade. Therefore, RNAi manipulates gene expression at a fine scale to cause a 'knockdown' in gene expression. In addition, RNAi can be 'multiplexed' as different RNA molecules can be introduced in order to target different mRNAs (see for example, Fellmann and Lowe 2014; Kennerdell and Carthew 1998), or the same mRNA in different regions (see for example, Gou et al. 2007). Furthermore, in nature dsRNA acts as a natural multiplexer because it is cut into multiple siRNAs that target different regions of the mRNA (Bernstein et al. 2001).

\section{3) The importance of an effector's activity and biological specificity}

The effector activity and specificity of a technique are critical to its success. If there are multiple techniques available to achieve the same experimental purpose, then the one with the greatest efficiency or superior type of specificity is preferred by the scientific community. For example, transcription activator-like effector nucleases (TALENs) are a technique derived from the bacteria Xanthomonas (Boch et al. 2009; Moscou and Bogdanove 2009). TALENs are similar to the CRISPR-Cas technique, as both are used for DNA editing. However, a TALENs' specificity is stereochemical so it needs to be reengineered for every experiment. Therefore, TALENs are not as easily programmable for a wide range of targets compared to CRISPR-Cas (with the notable limitation of the protospacer adjacent motif (Doudna and Charpentier 2014)). For this reason CRISPR-Cas became commercially viable and has replaced TALENs as the premier gene editing technique (Corbyn 2015; Doudna and Charpentier 2014). Therefore, the effector's 
activity and specificity are likely to be critical for the commercialisation of the technique for widespread usage.

Note that biologists implicitly recognise the importance of the effector's activity and the use of biological specificity for their molecular biology techniques. For example, many studies on RNAi discuss the technique's effector's activity (Fellmann and Lowe 2014; Filipowicz et al. 2005; Li et al. 2006; Rana 2007; Siomi and Siomi 2009; Vaucheret et al. 1998) and specificity (Bartel 2004; Elbashir et al. 2001b; Fellmann and Lowe 2014; Fire et al. 1998; Hamilton and Baulcombe 1999; Hammond et al. 2000; Hammond et al. 2001; Kennerdell and Carthew 1998; Parrish et al. 2000; Rana 2007; Siomi and Siomi 2009; Waterhouse et al. 1998; Waterhouse et al. 2001). In this section I have made theoretically explicit these two key characteristics of natural mechanisms: an effector's activity and the use of biological specificity.

\section{3) RNAi: a case study}

To answer the question of how a molecular biology technique is derived from nature requires an in-depth examination of how techniques are developed. In this section I describe in detail how the technique of RNAi was developed.

The development of RNAi was preceded by observations of gene-specific transcriptional inhibition when synthetic antisense RNA was introduced into an organism. Experiments in the bacteria Escherichia coli indicated that antisense RNA could bind to and inactivate mRNA (Light and Molin 1982). This phenomenon was then observed in many different organisms, including the nematode worm Caenorhabditis elegans (Izant and Weintraub 1984) and plants (Ecker and Davis 1986). At the same time, plant virologists showed that when a viral transgene was introduced into a plant the plant became resistant to the virus (Abel et al. 1986). These studies suggested that gene expression could be manipulated with the introduction of RNA.

Early studies discovered the RNAi mechanism in many different organisms, but the first study was conducted in plants. Napoli et al. (1990); van der Krol et al. (1990) wanted to increase colour intensity in the Petunia hybrida flower. They introduced a transgene (sense RNA) into the plant in order to overexpress a gene in the anthocyanin pathway, which controls formation of the flower pigment. Contrary to expectation, transformed flowers had less, rather than more, pigment. The synthetic sense RNA had reduced the mRNA of the endogenous gene. They termed this phenomenon 'co-suppression' (Napoli et al. 1990). In addition, Romano and Macino (1992) identified the RNAi phenomenon in a fungus, Neurospora crassa, and termed it 'quelling'. Also, studies in plants demonstrated that silencing occurred post-transcriptionally and therefore the RNAi phenomenon was sometimes referred to as 'post transcriptional gene silencing' (Blokland et al. 1994). At this time multiple studies were conducted on the introduction of RNA into $C$. elegans (Fire et al. 1991) (Fire et al. 1991; Guedes and Priess 1997; Guo and Kemphues 1995; Lin et al. 1995; Mello et al. 1996; Powell-Coffman et al. 1996). One of these C. elegans studies coined the term 'RNA-mediated interference' (Rocheleau et al. 1997). It is important to note that at this time microRNAs (miRNA), which are transcribed from the endogenous DNA and use the RNAi mechanism to regulate gene expression, were also identified (Lee et al. 1993; Wightman et al. 1993). These successive studies into how an organism actively responds to the introduction of RNA produced knowledge that was critical to the development of RNAi.

The RNAi technique was first applied in the paper 'Potent and specific genetic interference by double-stranded RNA in Caenorbabditis elegans' published in the journal Nature (Fire et al. 1998). 
In Fire et al. (1998, p. 807) dsRNA was investigated due to it being a contaminant in earlier experiments as it was found that:

... polymerases, although highly specific, produce some random or ectopic transcripts.

DNA transgene arrays also produce a fraction of aberrant RNA products ${ }^{3} \ldots$ we

surmised that the interfering RNA populations might include some molecules with double-stranded character.

dsRNA was accidently produced in these earlier experiments and caused the gene silencing.

Fire et al. (1998, p. 806) investigated dsRNA and identified that it is causally specific for the RNAi mechanism, they:

... investigate[d] the requirements for structure and delivery of the interfering RNA. To

our surprise, we found that double-stranded RNA was substantially more effective at producing interference than was either strand individually.

Therefore, the study tested the specificity of RNA molecules to control the RNAi mechanism.

The study was also a conclusive demonstration of how dsRNA can be used to control the RNAi mechanism and applied as a molecular biology technique to manipulate gene expression. Fire et al. $(1998$, p. 810$)$ concluded that RNAi:

... adds to the tools available for studying gene function in C. elegans. In particular, it should now be possible functionally to analyse many interesting coding regions ${ }^{21}$ for which no specific function has been defined.

Interestingly, Fire et al. (1998, p. 810) did not understand the biological function of the RNAi mechanism:

Whatever their target, the mechanisms underlying RNA interference probably exist for a biological purpose.

Immediately following publication of the Fire et al. (1998) paper, RNAi was shown to work in multiple organisms. Studies rapidly emerged describing RNAi's effectiveness in C. elegans (Fitzgerald and Schwarzbauer 1998; Montgomery et al. 1998; Ogg and Ruvkun 1998; Page and Winter 1998; Skop and White 1998; Tabuse et al. 1998; Timmons and Fire 1998); two species of plants, Nicotiana tabaccum and Oryza sativa (Waterhouse et al. 1998); and D. melanogaster

(Kennerdell and Carthew 1998). Attempts to conduct RNAi in mammals initially failed due to the immune response elicited, however, when siRNAs were introduced instead of dsRNA gene silencing occurred (Elbashir et al. 2001a). RNAi became a highly selective molecular biology technique for reducing expression of a target gene and today it is widely used for both basic and applied research (Deng et al. 2014; Fellmann and Lowe 2014; Mello and Conte 2004).

In the years following the Fire et al. (1998) paper, many components of the RNAi mechanism were identified and characterised. Biologists wondered how dsRNA could bind to the mRNA to cleave it and why a complete antisense RNA had never been detected in vivo. Biologists set out to look for fragments of the antisense RNA. They found small RNA fragments (antisense and sense) in plants and suggested that these were the molecules necessary for RNAi (Hamilton and Baulcombe 1999). Biologists also found that dsRNA is processed into small RNA fragments in D. melanogaster cells (Hammond et al. 2000; Zamore et al. 2000) and in C. elegans (Parrish et al. 2000). Small interfering RNAs (siRNA), 21-23 nucleotides in length, were identified as the common intermediary and their specificity guided the cleavage of the mRNA (Elbashir et al. 2001b). Biologists then needed to identify effectors for two distinct mechanistic steps: how dsRNA is cleaved into siRNA; and how the target mRNA is degraded.

The enzyme that cleaves a dsRNA into siRNAs was identified as a ribonuclease type III named Dicer (Bernstein et al. 2001). The endonuclease that cuts the target mRNA sequence-specifically was identified as Argonaute, which is part of the RNA-induced silencing complex (RISC) 
(Hammond et al. 2000; Martinez et al. 2002). Biologists then pursued the mechanistic details such as the functions of different forms of Dicer and Argonaute and how RISC works (Rana 2007). To this day the mechanism of RNAi is still being investigated.

In the following section I use the history of RNAi as the basis for an account of molecular biology technique development. I show that technique development can be demarcated into phases.

\section{4) Molecular biology technique development has four phases}

I propose that molecular biology techniques derived from natural systems have a specific pattern of development with four critical phases. These phases are: the discovery of a phenomenon; identification of the mechanism's trigger(s); application of the technique; and maturation of the technique. The eight molecular biology techniques I have explored in this paper show the four phases of technique development (Table 2).

The first phase is discovery - an interesting phenomenon is identified in a natural system. Biologists are curiosity driven and routinely identify and describe unusual phenomena. However, at this stage the underlying mechanism is not well characterised and the biological function of the mechanism is typically unknown.

The second phase is the identification of the trigger(s). The effector component of the mechanism is identified and the specificity is identified (see Table $3 A \& B$ ), note that for stereochemical techniques the effector is the specificity. If the effector is endogenous to the experimental system, then it does not need to be added to the experiment and its identification is not essential for the development of the technique. For example, the RNAi effector component was identified two years after the RNAi technique was developed (Table 2). I term the effector and specificity 'the trigger(s)' because they are the key causative agents and are 'the causally specific actual difference maker' under typical conditions (Carrier 2004; Waters 2007; Woodward 2010). Once biologists identify the trigger(s) they can use it to precisely access the causal structure of the mechanism.

The third phase is application of the trigger(s). In a conclusive demonstration that the trigger(s) is introduced into the experimental system and achieves some intended effect on the target of the specificity. The trigger(s) is exploited in three types of investigative strategies: to manipulate an effector's activity in a non-cellular experimental system, for example, restriction enzymes; to intervene on a cellular experimental system, for example, RNAi; or as a tracer to follow a natural process (for an in depth discussion see Griesemer 2007), for example, GFP (Table 1). At this stage a deep understanding of the mechanism underlying the technique is not necessary for the technique to work.

The fourth phase is maturation. Once the technique is established its performance can be improved. The scientific community invests considerable research activity into characterising, both spatially and temporally, the mechanism in natural systems. Therefore, the technique generates further research on the mechanism that underlies it. The new knowledge acquired may improve access to the mechanism or allow the technique to be better controlled, enabling the technique to continue to be refined. 
Table 2: The four phases of development for the eight highly successful molecular biology techniques. For each technique I identify the first paper that: discovered the phenomenon; identified the mechanism's effector; identified the mechanism's specificity applied the trigger(s); and any highly cited papers that demonstrate the maturation of the technique.

\begin{tabular}{|c|c|c|c|}
\hline $\begin{array}{l}\text { Technique (in } \\
\text { chronological } \\
\text { order of } \\
\text { development) }\end{array}$ & Phase & Reference & Description \\
\hline \multirow[t]{5}{*}{$\begin{array}{l}\text { 1. Restriction } \\
\text { enzymes }\end{array}$} & \multirow[t]{2}{*}{ Discovery } & $\begin{array}{l}\text { Luria and Human } \\
\qquad(1952)\end{array}$ & $\begin{array}{l}\text { Discovered that bacteriophage (T1, T2, T3, T4, T5, } \\
\mathrm{T} 6 \text { and T7) vary in their ability to grow in different } \\
\text { bacterial (Escherichia coli and Shigella dysenteriae) strains. }\end{array}$ \\
\hline & & $\begin{array}{l}\text { Dussoix and Arber } \\
\text { (1962) }\end{array}$ & $\begin{array}{l}\text { Discovered that bacteriophage } \lambda \text { DNA degrades in } \\
\text { Escherichia coli strains. }\end{array}$ \\
\hline & $\begin{array}{l}\text { Identification of } \\
\text { specificity/effector }\end{array}$ & $\begin{array}{l}\text { Kelly Jr and Smith } \\
(1970) ; \text { Smith and } \\
\text { Welcox }(1970)^{1}\end{array}$ & $\begin{array}{l}\text { Identified the nucleotide recognition sequence that } \\
\text { causes restriction enzymes (in particular, a type II } \\
\text { which recognises DNA and cuts sites at the same } \\
\text { place, endonuclease R from Hemophilus influenza) to } \\
\text { cut DNA. }\end{array}$ \\
\hline & Application of trigger & $\begin{array}{c}\text { Danna and } \\
\text { Nathans (1971) }\end{array}$ & $\begin{array}{l}\text { Applied restriction enzyme (endonuclease R from } \\
\text { Hemophilus influen₹a) to cut up DNA. }\end{array}$ \\
\hline & Maturation & $\begin{array}{c}\text { Feinberg and } \\
\text { Vogelstein (1983) }\end{array}$ & $\begin{array}{l}\text { Developed restriction enzymes using radiolabelling to } \\
\text { efficiently recover DNA fragments. }\end{array}$ \\
\hline \multirow[t]{6}{*}{$\begin{array}{l}\text { 2. DNA } \\
\text { sequencing }\end{array}$} & Discovery & $\begin{array}{l}\text { Watson and Crick } \\
\qquad(1953)\end{array}$ & $\begin{array}{l}\text { Discovered the complementary DNA structure in calf } \\
\text { thymus (possibly) and proposed a mechanism for } \\
\text { DNA replication. Also, predicted the existence of } \\
\text { DNA polymerase. }\end{array}$ \\
\hline & $\begin{array}{l}\text { Identification of } \\
\text { effector }\end{array}$ & $\begin{array}{l}\text { Kornberg et al. } \\
\quad(1956 \mathrm{~b})\end{array}$ & Identified DNA polymerase in Escherichia coli. \\
\hline & $\begin{array}{l}\text { Identification of } \\
\text { specificity }\end{array}$ & $\begin{array}{l}\text { Atkinson et al. } \\
\qquad(1969)\end{array}$ & $\begin{array}{l}\text { Identified that dideoxynucleotides cause DNA } \\
\text { polymerase to terminate synthesis of DNA. }\end{array}$ \\
\hline & Application of triggers & Sanger et al. (1977) & $\begin{array}{l}\text { Applied dideoxynucleotides with DNA polymerase } \\
\text { from Escherichia coli to determine the DNA sequence } \\
\text { of bacteriophage } \varphi \mathrm{X} 174 \text {. }\end{array}$ \\
\hline & \multirow[t]{2}{*}{ Maturation } & $\begin{array}{l}\text { The C. elegans } \\
\text { Sequencing } \\
\text { Consortium (1998) }\end{array}$ & $\begin{array}{l}\text { Developed DNA (Sanger) sequencing to sequence the } \\
\text { first multicellular organism (Caenorbabditis elegans) } \\
\text { genome. }\end{array}$ \\
\hline & & $\begin{array}{l}\text { International } \\
\text { Human Genome } \\
\text { Sequencing } \\
\text { Consortium (2001) }\end{array}$ & $\begin{array}{l}\text { Developed DNA (Sanger) sequencing to sequence the } \\
\text { human genome. }\end{array}$ \\
\hline \multirow[t]{3}{*}{ 3. PCR } & Discovery & $\begin{array}{l}\text { Watson and Crick } \\
\qquad(1953)\end{array}$ & $\begin{array}{l}\text { Discovered the complementary DNA structure in calf } \\
\text { thymus (possibly) and proposed a mechanism for } \\
\text { DNA replication. Also, predicted the existence of } \\
\text { DNA polymerase. }\end{array}$ \\
\hline & $\begin{array}{l}\text { Identification of } \\
\text { effector }\end{array}$ & $\begin{array}{l}\text { Kornberg et al. } \\
\quad(1956 b)\end{array}$ & Identified DNA polymerase in Escherichia coli. \\
\hline & $\begin{array}{l}\text { Identification of } \\
\text { specificity }\end{array}$ & $\begin{array}{l}\text { Kornberg et al. } \\
\quad(1956 a)\end{array}$ & $\begin{array}{l}\text { Identified that a primer causes DNA polymerase to } \\
\text { initiate synthesis of DNA. }\end{array}$ \\
\hline
\end{tabular}




\begin{tabular}{|c|c|c|c|}
\hline & \multirow[t]{2}{*}{ Application of triggers } & $\begin{array}{l}\text { Kleppe et al. } \\
\qquad(1971)^{2}\end{array}$ & $\begin{array}{l}\text { Applied primers with DNA polymerase from } 3 \\
\text { species (Escherichia coli, Microccus luteus and T4) to } \\
\text { replicate short synthetic DNA. }\end{array}$ \\
\hline & & Saiki et al. (1985) & $\begin{array}{l}\text { Applied primers with DNA polymerase from } \\
\text { Escherichia coli to amplify DNA region. }\end{array}$ \\
\hline & Maturation & Saiki et al. (1988) & $\begin{array}{l}\text { Developed PCR to be thermostable using DNA } \\
\text { polymerase from Thermus aquaticus. }\end{array}$ \\
\hline \multirow[t]{7}{*}{ 4. Gene targeting } & Discovery & $\begin{array}{l}\text { Gluzman et al. } \\
\text { (1977); Vogel et al. } \\
(1977)^{1}\end{array}$ & $\begin{array}{l}\text { Discovered that a mutant phenotype can be rescued } \\
\text { in a simian virus } 40 \text { (SV40) temperature-sensitive } \\
\text { mutant (tsD202) when added to monkey CV1 cells } \\
\text { (containing endogenous integrated SV40). Also, } \\
\text { discovered that the rescue is due to recombination. }\end{array}$ \\
\hline & $\begin{array}{l}\text { Identification of } \\
\text { specificity }\end{array}$ & $\begin{array}{l}\text { Hinnen et al. } \\
\quad(1978)\end{array}$ & $\begin{array}{l}\text { Identified that exogenous DNA of LEU2 causes site } \\
\text { specific recombination with homologous } \\
\text { chromosomal DNA in Saccharomyces cerevisiae. }\end{array}$ \\
\hline & Application of trigger & $\begin{array}{l}\text { Smithies et al. } \\
\text { (1985) }\end{array}$ & $\begin{array}{l}\text { Applied exogenous DNA to modify only the target } \\
\text { gene ( } \beta \text {-globin) in human cells. }\end{array}$ \\
\hline & \multirow[t]{3}{*}{ Maturation } & $\begin{array}{l}\text { Thomas and } \\
\text { Capecchi (1987) }\end{array}$ & $\begin{array}{l}\text { Developed gene targeting to inactivate an endogenous } \\
\text { gene (hptr) in mouse embryonic stem cells. }\end{array}$ \\
\hline & & $\begin{array}{l}\text { Doetschman et al. } \\
\text { (1987) }\end{array}$ & $\begin{array}{l}\text { Developed gene targeting to correct mutant } h p t r \text { in } \\
\text { mouse embryonic stem cells. }\end{array}$ \\
\hline & & $\begin{array}{l}\text { Mansour et al. } \\
\quad(1988)\end{array}$ & $\begin{array}{l}\text { Developed gene targeting selection (positive for cells } \\
\text { that have incorporated exogenous DNA and negative } \\
\text { for cells that have randomly incorporated exogenous } \\
\text { DNA) in mouse embryonic stem cells. }\end{array}$ \\
\hline & $\begin{array}{l}\text { Identification of } \\
\text { effector }\end{array}$ & $\mathrm{N} / \mathrm{A}^{3}$ & $\begin{array}{l}\text { Endogenous endonucleases create a double-stranded } \\
\text { break and this initiates repair pathway. For example, } \\
\text { SPO11. }\end{array}$ \\
\hline \multirow[t]{6}{*}{ 5. GFP } & Discovery & $\begin{array}{l}\text { Davenport and } \\
\text { Nicol (1955) }\end{array}$ & Discovered the green fluorescence in Aequorea victoria. \\
\hline & $\begin{array}{l}\text { Identification of } \\
\text { effector }\end{array}$ & $\begin{array}{l}\text { Shimomura et al. } \\
\qquad(1962)\end{array}$ & Identified GFP in Aequorea victoria. \\
\hline & $\begin{array}{l}\text { Identification of } \\
\text { specificity }\end{array}$ & $\begin{array}{l}\text { Prasher et al. } \\
\quad(1992)\end{array}$ & $\begin{array}{l}\text { Identified the genomic DNA and cDNA sequence of } \\
\text { GFP that causes fluorescence in Aequorea victoria. }\end{array}$ \\
\hline & Application of trigger & $\begin{array}{l}\text { Chalfie et al. } \\
\text { (1994) }\end{array}$ & $\begin{array}{l}\text { Applied GFP cDNA to generate fluorescence in E. } \\
\text { coli and Caenorbabditis elegans cells. }\end{array}$ \\
\hline & \multirow[t]{2}{*}{ Maturation } & Heim et al. (1995) & $\begin{array}{l}\text { Developed GFP spectral characteristics using a point } \\
\text { mutation in Escherichia coli. }\end{array}$ \\
\hline & & $\begin{array}{l}\text { Cormack et al. } \\
\text { (1996) }\end{array}$ & $\begin{array}{l}\text { Developed GFP variants that fluoresce more } \\
\text { intensely in Escherichia coli. }\end{array}$ \\
\hline \multirow[t]{4}{*}{ 6. RNAi } & Discovery & Napoli et al. (1990) & $\begin{array}{l}\text { Discovered the knockdown of chalcone synthase in } \\
\text { Petunia bybrida. }\end{array}$ \\
\hline & $\begin{array}{l}\text { Identification of } \\
\text { specificity ( }\left(1^{\text {st }} \text { step) } \&\right. \\
\text { application of trigger }\end{array}$ & Fire et al. (1998) & $\begin{array}{l}\text { Identified that dsRNA causes sequence specific } \\
\text { regulation of mRNA in Caenorbabditis elegans. } \\
\text { Applied dsRNA to knockdown gene expression in } \\
\text { Caenorbabditis elegans. }\end{array}$ \\
\hline & $\begin{array}{l}\text { Identification of } \\
\text { specificity (2 } 2^{\text {nd }} \text { step) }\end{array}$ & $\begin{array}{c}\text { Hamilton and } \\
\text { Baulcombe (1999) }\end{array}$ & $\begin{array}{l}\text { Identified that siRNA (processed product of dsRNA) } \\
\text { causes sequence specific regulation of mRNA in } \\
\text { plants. }\end{array}$ \\
\hline & $\begin{array}{l}\text { Identification of } \\
\text { effector }\end{array}$ & $\begin{array}{l}\text { Hammond et al. } \\
(2000)\end{array}$ & $\begin{array}{l}\text { Identified the RNA-induced silencing complex (RISC) } \\
\text { which contains an endonuclease that cleaves target } \\
\text { mRNA in Drosophila cells. }\end{array}$ \\
\hline
\end{tabular}




\begin{tabular}{|c|c|c|c|}
\hline & Maturation & $\begin{array}{l}\text { Elbashir et al. } \\
\text { (2001a) }\end{array}$ & $\begin{array}{l}\text { Developed RNAi to knockdown gene expression in } \\
\text { mammalian and Drosophila cells. }\end{array}$ \\
\hline \multirow[t]{3}{*}{ 7. iPS } & Discovery & Gurdon (1962) & $\begin{array}{l}\text { Discovered that cell differentiation is reversible } \\
\text { because the nucleus of a somatic cell can successfully } \\
\text { replace the nucleus of an egg cell in Xenopus laevis. }\end{array}$ \\
\hline & $\begin{array}{l}\text { Identification of } \\
\text { specificity/effector } \& \\
\text { application of trigger }\end{array}$ & $\begin{array}{l}\text { Takahashi and } \\
\text { Yamanaka (2006) }\end{array}$ & $\begin{array}{l}\text { Identified the genome and transcriptome changes that } \\
\text { cause four transcription factors (Oct } 3 / 4 \text {, Sox } 2 \text {, c-Myc } \\
\text { and Klf4 in mice) to make somatic cells become } \\
\text { pluripotent stem cells. } \\
\text { Applied the four transcription factors cDNA to } \\
\text { reprogram embryonic and adult fibroblast mice cells. }\end{array}$ \\
\hline & Maturation & $\begin{array}{l}\text { Takahashi et al. } \\
\text { (2007) }\end{array}$ & Developed iPS in human cells. \\
\hline \multirow[t]{6}{*}{ 8. CRISPR-Cas } & Discovery & Ishino et al. (1987) & $\begin{array}{l}\text { Discovered the CRISPR motif (repeated sequence } \\
\text { with spacers) in the DNA sequence of Escherichia coli. }\end{array}$ \\
\hline & $\begin{array}{l}\text { Identification of } \\
\text { effector }\end{array}$ & $\begin{array}{l}\text { Makarova et al. } \\
\qquad(2002)\end{array}$ & $\begin{array}{l}\text { Identified the CRISPR-associated (cas) genes in the } \\
\text { genome sequences of bacteria and archaea. In } \\
\text { particular, the class 2, Type II (recognises DNA and } \\
\text { cleavage results in double-stranded break) Cas9 } \\
\text { (COG3513) in Streptococcus pyogenes, Campylobacter jejuni, } \\
\text { Neisseria meningitidis and Pasteurella multocida. }\end{array}$ \\
\hline & $\begin{array}{l}\text { Identification of } \\
\text { specificity (part 1) }\end{array}$ & $\begin{array}{l}\text { Brouns et al. } \\
\qquad(2008)\end{array}$ & $\begin{array}{l}\text { Identified that CRISPR RNAs (crRNAs) causes Cas } \\
\text { to sequence specifically cleave DNA in Eschericbia coli. }\end{array}$ \\
\hline & $\begin{array}{c}\text { Identification of } \\
\text { specificity (part 2) \& } \\
\text { application of triggers }\end{array}$ & Jinek et al. (2012) & $\begin{array}{l}\text { Identified that crRNA and trans-activating CRISPR } \\
\text { RNA (tracrRNA) must complementary base pair to } \\
\text { cause Cas to site-specifically cleave DNA. } \\
\text { Applied a tracrRNA-crRNA complex (the 'single- } \\
\text { guide RNA') with Cas9 from Streptococcus pyogenes to } \\
\text { cleave DNA. }\end{array}$ \\
\hline & \multirow[t]{2}{*}{ Maturation } & Cong et al. (2013) & \multirow{2}{*}{$\begin{array}{l}\text { Developed CRISPR-Cas to edit the genome of } \\
\text { mammalian (human and mouse) cells. }\end{array}$} \\
\hline & & Mali et al. (2013) & \\
\hline
\end{tabular}

${ }^{1}$ This paper was published in two parts.

${ }^{2}$ This study only applied primers with DNA polymerase to synthesise DNA rather than amplify a DNA region.

${ }^{3}$ A single study cannot be identified because the biological mechanism underlying gene targeting has multiple effectors. 
Table 3: The key experiments for the RNAi technique conducted by Fire et al. (1998). Experiments that (A) identified the triggers in the RNAi mechanism; and (B) identified the target of the specificity in the RNAi mechanism.

(A)

\begin{tabular}{|c|c|c|}
\hline Specificity & Range tested & Result \\
\hline $\begin{array}{l}\text { Non-purified single- } \\
\text { stranded RNA } \\
\text { (ssRNA) }\end{array}$ & Sense RNA or antisense RNA & $\begin{array}{l}\text { When non-purified ssRNA was introduced into the experimental } \\
\text { system RNAi occurred. }\end{array}$ \\
\hline Purified ssRNA & Sense RNA or antisense RNA & $\begin{array}{l}\text { Purified ssRNA led to weaker RNAi compared to purified dsRNA, } \\
\text { indicated that dsRNA causes RNAi. }\end{array}$ \\
\hline $\begin{array}{l}\text { Complementary sense } \\
\text { and antisense strand } \\
\text { RNA }\end{array}$ & $\begin{array}{l}\text { Pre-annealed; injected } \\
\text { sequentially; or injected } \\
\text { sequentially but with long time } \\
\text { interval between RNAs }\end{array}$ & $\begin{array}{l}\text { Pre-annealing of RNA led to stronger RNAi, indicated that the } \\
\text { formation of dsRNA was important for RNAi. } \\
\text { Sequential injection of sense and antisense RNA led to RNAi, } \\
\text { indicated that RNA strands could hybridise to form dsRNA in the } \\
\text { experimental system. } \\
\text { If there was a long time interval between sequential injection of } \\
\text { RNAs no RNAi occurred, indicated that over time ssRNA are } \\
\text { degraded or become inaccessible in the experimental system. }\end{array}$ \\
\hline $\begin{array}{l}\text { Time post-injection } \\
\text { of RNA }\end{array}$ & $6 ; 15 ; 27 ; 41 ;$ or 56 hours & $\begin{array}{l}\text { When there was a long time interval after RNA was introduced into } \\
\text { the experimental system RNAi decreased. }\end{array}$ \\
\hline $\begin{array}{l}\text { ssRNA and control } \\
\text { gene dsRNA }\end{array}$ & $\begin{array}{l}\text { ssRNA not attached to dsRNA; } \\
\text { ssRNA attached at its 5' end to } \\
\text { dsRNA; or ssRNA attached at } \\
\text { its 3' end to dsRNA }\end{array}$ & $\begin{array}{l}\text { For the gene that the ssRNA targeted no RNAi occurred, indicated } \\
\text { that sequence specificity not double stranded structure was } \\
\text { important for RNAi. }\end{array}$ \\
\hline dsRNA length & 299 to 1033 nucleotides & Nucleotide length of dsRNA did not affect RNAi. \\
\hline RNA dosage & $\begin{array}{l}30,000 \text { to } 3,600,000 \mathrm{RNA} \\
\text { molecules per organism }\end{array}$ & $\begin{array}{l}\text { Very low dsRNA dosages triggered RNAi, indicated that RNAi is a } \\
\text { catalytic process (i.e. enzymes involved) otherwise there would be } \\
\text { not enough RNA molecules to bind to all the endogenous mRNA in } \\
\text { the experimental system. }\end{array}$ \\
\hline $\begin{array}{l}\text { Site of injection of } \\
\text { RNA in organism }\end{array}$ & $\begin{array}{l}\text { Body cavity of head; body } \\
\text { cavity of tail; or gonad }\end{array}$ & $\begin{array}{l}\text { In tissues other than the ones injected RNAi occurred, indicated that } \\
\text { RNAi is systemic. Also, injection of adults sometimes led to } \\
\text { offspring with RNAi, indicated that trans-generational inheritance of } \\
\text { RNAi occurred. These results suggested that the RNAi mechanism } \\
\text { existed throughout the whole organism. }\end{array}$ \\
\hline
\end{tabular}

(B)

\begin{tabular}{|c|c|c|}
\hline Target of specificity & Range tested & Result \\
\hline Gene regions & $\begin{array}{l}\text { One exon, } \\
\text { multiple exons; } \\
\text { intron; or } \\
\text { promoter }\end{array}$ & $\begin{array}{l}\text { RNAi occurred only when the coding sequence of the mRNA was targeted, } \\
\text { indicated that RNAi works through post-transcriptional regulation. }\end{array}$ \\
\hline $\begin{array}{l}\text { Conserved gene } \\
\text { segment }\end{array}$ & & $\begin{array}{l}\text { RNAi led to an unexpected phenotype, indicated that RNAi affects genes with a } \\
\text { similar sequence to the gene of interest. }\end{array}$ \\
\hline Gene of interest & $\begin{array}{l}\text { unc-22; unc-54; fem- } \\
1 ; \text { blh-1; } \text {;fp; or } \\
\text { mex-3 }\end{array}$ & $\begin{array}{l}\text { The target of RNAi was genes that are non-essential and have previously been } \\
\text { characterised with an easily identifiable visual phenotype. Also, the relationship } \\
\text { between the gene's expression and phenotype was in the manipulable direction } \\
\text { (i.e. reduced expression increased the severity of the phenotype). }\end{array}$ \\
\hline $\begin{array}{l}\text { Transgenic line } \\
\text { expressing two GFP } \\
\text { reporter proteins }\end{array}$ & & RNAi occurred in individual cells of the organism. \\
\hline $\begin{array}{l}\text { mex-3 in an in situ } \\
\text { hybridisation } \\
\text { experiment }\end{array}$ & & $\begin{array}{l}\text { The target of RNAi was a gene that is abundant in early embryos (a useful } \\
\text { developmental period for an in situ experiment). RNAi was demonstrated visually } \\
\text { as the endogenous mRNA disappeared suggesting it was destroyed, indicated that } \\
\text { mRNA (not precursor mRNA nor protein) was the target of RNAi. }\end{array}$ \\
\hline
\end{tabular}




\section{1) Cognitive values and the success of the techniques}

Cognitive values play an important role in the assessment of theory change in the sciences (Darden 1991; Douglas 2013; Kuhn 1977). Here I identify the cognitive values that are important for the widespread adoption of a technique. Three cognitive values are important for the assessment of a technique. First, the technique needs to be fruitful for further research.

Techniques need to generate new knowledge and open up areas of research that were previously unimaginable. For example, RNAi has helped biologists manipulate RNA thus leading to a more sophisticated understanding of the function of RNA (Mello and Conte 2004) and this has allowed biologists to manipulate genes that are lethal in development in order to investigate their functions (for example, Fitzgerald and Schwarzbauer 1998). Second, the technique should allow expansion of its scope of application far beyond its original biological context. After the effector protein is identified it must either be endogenous to the experimental system (and also conserved in the taxa that will be the experimental system) or be exogenous and able to operate in a range of experimental systems. A technique that has applications in many contexts means a bigger scientific community can use the technique. In addition, a technique that can be used in mammals is particularly desired due to the value placed on medical and therapeutic research. For example, the RNAi effector, RISC, is present in all eukaryotes (Cerutti and Casas-Mollano 2006) and RNAi can be used in human cell lines (Elbashir et al. 2001a). Third, the technique needs to have extendability. The technique should accommodate modifications so that it can be used for different or expanded capabilities. Therefore, a technique can become the progenitor for a family of related techniques. For example, a form of RNAi was developed that used RNA molecules targeted at promoters to increase rather than decrease gene expression ( $\mathrm{Li}$ et al. 2006). It is important to note that whether a technique rates highly on these three cognitive values it can only be identified in hindsight as that judgment is based on the employment of the technique (Darden 1991; Douglas 2013). The three cognitive values I have identified do not compete with one another as similar theoretical values do (Darden 1991) - a technique can be fruitful, have broad scope and be extendable at the same time.

\section{5) Conclusions}

A deeper understanding of the characteristics of natural systems and the development of scientific practice is gained by examining how molecular biology techniques are developed by biologists. In this paper I have investigated eight highly successful techniques of molecular biology that are derived from natural systems. I have argued that the development of these techniques falls into four phases. What are the implications of the fact that biologists develop molecular biology techniques from natural systems? Biologists' knowledge about natural systems limits what can be developed as a technique. Molecular biology techniques, and therefore molecular biology knowledge, are contingent. If biologists had discovered different phenomena in natural systems in the past then different techniques would have been developed. Molecular biology knowledge would have been altogether different, although we might speculate that deeply entrenched biological processes that are highly conserved across taxa (for example, the RNAi mechanism) will always be discovered.

There are other molecular biology techniques that are derived from natural systems and are likely to use the four phases of development of a molecular technique. These include techniques such as: reverse transcription; molecular cloning; monoclonal antibodies; site directed mutagenesis; and immunotherapy. Further research could identify these techniques' effector's activity and specificity. 
It is an open question whether molecular biology will continue to progress through the development of molecular techniques derived from natural systems. Perhaps knowledge construction in molecular biology requires a natural systems strategy. Alternatively, as a relatively immature science that is still discovering its fundamental phenomena, adopting this strategy could be just an immature stage for molecular biology. There is some evidence that biologists working on synthetic biology have started to use rational design in organisms, for example, the high profile 'Human Genome Project-Write' (Boeke et al. 2016). However, biologists often find that rational design is not optimal and that selection methods lead to improved technique development and outcomes (Silverman 2003). Furthermore, a rational design strategy cannot be used to access the causal structure of molecular mechanisms when no comprehensive understanding of these mechanisms exists.

The addition of new molecular biology techniques accelerate research, transform biological knowledge and generates new knowledge that would otherwise not exist. A new technique can help uncover previously undetected phenomena and paradoxically, in turn lead to the development of yet another technique. Therefore, the techniques in molecular biology build upon one another and are cumulative.

Perhaps it is the fact that molecular biology's scientific practice is based on a collection of research tools, that makes it such a unique area of the biological sciences (Burian 1993).

Biologists imbue their explanations of molecular mechanisms with the techniques they use to investigate the mechanisms (Trujillo et al. 2015). In molecular biology, even more than in other areas of science, the development of technological capabilities and scientific knowledge are inextricably linked.

\section{Acknowledgements}

I thank Paul Griffiths for all of his excellent advice, from when this project was an abstract idea and spanned across the paper's many iterations. I would also like to thank the participants of the 'Reductionism and Integration, Bioethics and Behavior: A Conference Celebrating the Career of Kenneth F. Schaffner' (Centre for Philosophy of Science, University of Pittsburgh) for their feedback when I presented this paper, in particular my commentator William Wimsatt. I am also grateful to Nicolas Rasmussen, Alan Love, members of the Theory and Method in Bioscience group (The University of Sydney) and members of the Behaviour and Genetics of Social Insects Laboratory (The University of Sydney) for their thoughtful comments that improved earlier versions of this paper. Finally, thank you to Lindell Bromham for encouraging me to pursue this project and for telling me to start writing this paper, when I was in the midst of my laboratory experiments. 


\section{References}

Abel PP, Nelson RS, De B, Hoffmann N, Rogers SG, Fraley RT, Beachy RN (1986) Delay of disease development in transgenic plants that express the tobacco mosaic virus coat protein gene. Science 232:738-743

Ankeny RA (2000) Fashioning descriptive models in biology: Of worms and wiring diagrams. Philosophy of Science:260-272

Atkinson MR, Deutscher MP, Kornberg A, Russell AF, Moffatt J (1969) Enzymatic synthesis of deoxyribonucleic acid. XXXIV. Termination of chain growth by a 2', 3'dideoxyribonucleotide. Biochemistry 8:4897-4904

Bartel DP (2004) MicroRNAs: Genomics, Biogenesis, Mechanism, and Function. Cell 116:281297

Bellés X (2010) Beyond Drosophila: RNAi in vivo and functional genomics in insects. Annu Rev Entomol 55:111-128

Bernstein E, Caudy AA, Hammond SM, Hannon GJ (2001) Role for a bidentate ribonuclease in the initiation step of RNA interference. Nature 409:363-366

Bhaya D, Davison M, Barrangou R (2011) CRISPR-Cas Systems in Bacteria and Archaea: Versatile Small RNAs for Adaptive Defense and Regulation. Annu Rev Genet 45:273297

Blokland Rv, Geest N, Mol J, Kooter J (1994) Transgene-mediated suppression of chalcone synthase expression in Petunia bybrida results from an increase in RNA turnover. The Plant Journal 6:861-877

Boch J et al. (2009) Breaking the Code of DNA Binding Specificity of TAL-Type III Effectors. Science 326:1509-1512

Boeke JD et al. (2016) The Genome Project-Write. Science

Brouns SJ et al. (2008) Small CRISPR RNAs guide antiviral defense in prokaryotes. Science 321:960-964

Burian RM (1993) Technique, task definition, and the transition from genetics to molecular genetics: Aspects of the work on protein synthesis in the laboratories of J. Monod and P. Zamecnik. J Hist Biol 26:387-407

Carrier M (2004) Knowledge and Control: On the Bearing of Epistemic Values in Applied Science. In: Machamer P, Wolters G (eds) Science, values,

and objectivity. University of Pittsburgh Press, Pittsburgh, United States of America, pp 275-293

Carrington JC, Ambros V (2003) Role of microRNAs in plant and animal development. Science 301:336

Cerutti H, Casas-Mollano JA (2006) On the origin and functions of RNA-mediated silencing: from protists to man. Curr Genet 50:81-99

Chalfie M, Tu Y, Euskirchen G, Ward WW, Prasher DC (1994) Green fluorescent protein as a marker for gene expression. Science 263:802-805

Cong L et al. (2013) Multiplex Genome Engineering Using CRISPR/Cas Systems. Science 339:819-823

Corbyn Z (2015) Biology's big hit. Nature 528:S4-S5

Cormack BP, Valdivia RH, Falkow S (1996) FACS-optimized mutants of the green fluorescent protein (GFP). Gene 173:33-38

Danna K, Nathans D (1971) Specific cleavage of simian virus 40 DNA by restriction endonuclease of Hemophilus influenzae. Proceedings of the National Academy of Sciences 68:2913-2917

Darden L (1991) Theory change in science: Strategies from Mendelian genetics. Oxford University Press, Oxford, United Kingdom

Davenport D, Nicol J (1955) Luminescence in Hydromedusae. Proceedings of the Royal Society of London B: Biological Sciences 144:399-411 
Deng Y et al. (2014) Therapeutic potentials of gene silencing by RNA interference: Principles, challenges, and new strategies. Gene 538:217-227

Doetschman T, Gregg RG, Maeda N, Hooper ML, Melton DW, Thompson S, Smithies O (1987) Targetted correction of a mutant HPRT gene in mouse embryonic stem cells. Nature 330:576-578

Doudna JA, Charpentier E (2014) The new frontier of genome engineering with CRISPR-Cas9. Science 346

Douglas H (2013) The Value of Cognitive Values. Philosophy of Science 80:796-806

Dussoix D, Arber W (1962) Host specificity of DNA produced by Escherichia coli: II. Control over acceptance of DNA from infecting phage $\lambda$. J Mol Biol 5:37-49

Ecker JR, Davis RW (1986) Inhibition of gene expression in plant cells by expression of antisense RNA. Proceedings of the National Academy of Sciences 83:5372-5376

Elbashir SM, Harborth J, Lendeckel W, Yalcin A, Weber K, Tuschl T (2001a) Duplexes of 21nucleotide RNAs mediate RNA interference in cultured mammalian cells. Nature 411:494-498

Elbashir SM, Lendeckel W, Tuschl T (2001b) RNA interference is mediated by 21-and 22nucleotide RNAs. Genes Dev 15:188-200

Feinberg AP, Vogelstein B (1983) A technique for radiolabeling DNA restriction endonuclease fragments to high specific activity. Anal Biochem 132:6-13

Fellmann C, Lowe SW (2014) Stable RNA interference rules for silencing. Nat Cell Biol 16:10-18

Filipowicz W, Jaskiewicz L, Kolb FA, Pillai RS (2005) Post-transcriptional gene silencing by siRNAs and miRNAs. Curr Opin Struct Biol 15:331-341

Fire A, Albertson D, Harrison SW, Moerman DG (1991) Production of antisense RNA leads to effective and specific inhibition of gene expression in C. elegans muscle. Development 113:503-514

Fire A, Xu S, Montgomery MK, Kostas SA, Driver SE, Mello CC (1998) Potent and specific genetic interference by double-stranded RNA in Caenorbabditis elegans. Nature 391:806-811

Fitzgerald MC, Schwarzbauer JE (1998) Importance of the basement membrane protein SPARC for viability and fertility in Caenorhabditis elegans. Curr Biol 8:1285-S1281

Gluzman Y, Kuff EL, Winocour E (1977) Recombination Between Endogenous and Exogenous Simian Virus 40 Genes: I. Rescue of a Simian Virus 40 Temperature-Sensitive Mutant by Passage in Permissive Transformed Monkey Lines. J Virol 24:534-540

Gou D et al. (2007) A novel approach for the construction of multiple shRNA expression vectors. The Journal of Gene Medicine 9:751-763

Griesemer J (2007) Tracking organic processes: Representations and research styles in classical embryology and genetics. In: Maienschein J, Laubichler M (eds) From Embryology to Evo-Devo. MIT Press, Cambridge, USA, pp 375-433

Griffiths P, Stotz K (2013) Genetics and Philosophy: An Introduction. Cambridge University Press, Cambridge, England

Griffiths PE, Pocheville A, Calcott B, Stotz K, Kim H, Knight R (2015) Measuring Causal Specificity. Philosophy of Science 82:529-555

Guedes S, Priess JR (1997) The C. elegans MEX-1 protein is present in germline blastomeres and is a $\mathrm{P}$ granule component. Development 124:731-739

Guo S, Kemphues KJ (1995) par-1, a gene required for establishing polarity in C. elegans embryos, encodes a putative Ser/Thr kinase that is asymmetrically distributed. Cell 81:611-620

Gurdon JB (1962) The developmental capacity of nuclei taken from intestinal epithelium cells of feeding tadpoles. J Embryol Exp Morphol 10:622-640

Hamilton AJ, Baulcombe DC (1999) A Species of Small Antisense RNA in Posttranscriptional Gene Silencing in Plants. Science 286:950-952

Hammond SM, Bernstein E, Beach D, Hannon GJ (2000) An RNA-directed nuclease mediates post-transcriptional gene silencing in Drosophila cells. Nature 404:293-296 
Hammond SM, Caudy AA, Hannon GJ (2001) Post-transcriptional gene silencing by doublestranded RNA. Nat Rev Genet 2:110-119

Heim R, Cubitt AB, Tsien RY (1995) Improved green fluorescence. Nature 373:663-664

Hinnen A, Hicks JB, Fink GR (1978) Transformation of yeast. Proceedings of the National Academy of Sciences 75:1929-1933

International Human Genome Sequencing Consortium (2001) Initial sequencing and analysis of the human genome. Nature 409:860-921

Ishino Y, Shinagawa H, Makino K, Amemura M, Nakata A (1987) Nucleotide sequence of the iap gene, responsible for alkaline phosphatase isozyme conversion in Escherichia coli, and identification of the gene product. J Bacteriol 169:5429-5433

Izant JG, Weintraub H (1984) Inhibition of thymidine kinase gene expression by anti-sense RNA: A molecular approach to genetic analysis. Cell 36:1007-1015

Jinek M, Chylinski K, Fonfara I, Hauer M, Doudna JA, Charpentier E (2012) A Programmable Dual-RNA-Guided DNA Endonuclease in Adaptive Bacterial Immunity. Science 337:816-821

Kelly Jr TJ, Smith HO (1970) A restriction enzyme from Hemophilus influenzae: II. Base sequence of the recognition site. J Mol Biol 51:393-409

Kennerdell JR, Carthew RW (1998) Use of dsRNA-Mediated Genetic Interference to Demonstrate that frizzled and frizzled 2 Act in the Wingless Pathway. Cell 95:1017-1026

Kleppe K, Ohtsuka E, Kleppe R, Molineux I, Khorana H (1971) Studies on polynucleotides: XCVI. Repair replication of short synthetic DNA's as catalyzed by DNA polymerases. J Mol Biol 56:341-361

Kornberg A, Lehman I, Bessman MJ, Simms E (1956a) Enzymic synthesis of deoxyribonucleic acid. Biochim Biophys Acta 21:197-198

Kornberg A, Lehman I, Simms E (1956b) Polydesoxyribonucleotide synthesis by enzymes from Escherichia coli. Fed Proc 15:291-292

Kuhn TS (1977) Objectivity, Value Judgment, and Theory Choice. In: The Essential Tension: Selected Studies in Scientific Tradition and Change. University of Chicago Press, Chicago, USA, pp 320-329

Lander Eric S (2016) The Heroes of CRISPR. Cell 164:18-28

Lee RC, Feinbaum RL, Ambros V (1993) The C. elegans heterochronic gene lin-4 encodes small RNAs with antisense complementarity to lin-14. Cell 75:843-854

Li L-C et al. (2006) Small dsRNAs induce transcriptional activation in human cells. Proceedings of the National Academy of Sciences 103:17337-17342

Light J, Molin S (1982) The sites of action of the two copy number control functions of plasmid R1. Molecular and General Genetics MGG 187:486-493

Lin R, Thompson S, Priess JR (1995) pop-1 encodes an HMG box protein required for the specification of a mesoderm precursor in early C. elegans embryos. Cell 83:599-609

Luria SE, Human ML (1952) A nonhereditary, host-induced variation of bacterial viruses. J Bacteriol 64:557-569

Makarova KS, Aravind L, Grishin NV, Rogozin IB, Koonin EV (2002) A DNA repair system specific for thermophilic Archaea and bacteria predicted by genomic context analysis. Nucleic Acids Res 30:482-496

Mali P et al. (2013) RNA-Guided Human Genome Engineering via Cas9. Science 339:823-826

Mansour SL, Thomas KR, Capecchi MR (1988) Disruption of the proto-oncogene int-2 in mouse embryo-derived stem cells: a general strategy for targeting mutations to nonselectable genes. Nature 336:348-352

Martinez J, Patkaniowska A, Urlaub H, Lührmann R, Tuschl T (2002) Single-stranded antisense siRNAs guide target RNA cleavage in RNAi. Cell 110:563-574

Mello CC, Conte D (2004) Revealing the world of RNA interference. Nature 431:338-342 
Mello CC, Schubert C, Draper B, Zhang W, Lobel R, Priess JR (1996) The PIE-1 protein and germline specification in C. elegans embryos. Nature 382:710-712

Montgomery MK, Xu S, Fire A (1998) RNA as a target of double-stranded RNA-mediated genetic interference in Caenorbabditis elegans. Proceedings of the National Academy of Sciences 95:15502-15507

Moscou MJ, Bogdanove AJ (2009) A Simple Cipher Governs DNA Recognition by TAL Effectors. Science 326:1501-1501

Napoli C, Lemieux C, Jorgensen R (1990) Introduction of a Chimeric Chalcone Synthase Gene into Petunia Results in Reversible Co-Suppression of Homologous Genes in trans. The Plant Cell 2:279-289

Ogg S, Ruvkun G (1998) The C. elegans PTEN homolog, DAF-18, acts in the insulin receptorlike metabolic signaling pathway. Mol Cell 2:887-893

Page AP, Winter AD (1998) A divergent multi-domain cyclophilin is highly conserved between parasitic and free-living nematode species and is important in larval muscle development. Mol Biochem Parasitol 95:215-227

Parrish S, Fleenor J, Xu S, Mello C, Fire A (2000) Functional anatomy of a dsRNA trigger: differential requirement for the two trigger strands in RNA interference. Mol Cell 6:1077-1087

Powell-Coffman JA, Knight J, Wood WB (1996) Onset of C. elegans Gastrulation Is Blocked by Inhibition of Embryonic Transcription with an RNA Polymerase Antisense RNA. Dev Biol 178:472-483

Prasher DC, Eckenrode VK, Ward WW, Prendergast FG, Cormier MJ (1992) Primary structure of the Aequorea victoria green-fluorescent protein. Gene 111:229-233

Rana TM (2007) Illuminating the silence: understanding the structure and function of small RNAs. Nature reviews Molecular cell biology 8:23-36

Rocheleau CE et al. (1997) Wnt signaling and an APC-related gene specify endoderm in early $C$. elegans embryos. Cell 90:707-716

Romano N, Macino G (1992) Quelling: transient inactivation of gene expression in Neurospora crassa by transformation with homologous sequences. Mol Microbiol 6:3343-3353

Ronai I, Oldroyd BP, Barton DA, Cabanes G, Lim J, Vergoz V (2016) Anarchy is a molecular signature of worker sterility in the honey bee. Mol Biol Evol 33:134-142

Saiki R et al. (1988) Primer-directed enzymatic amplification of DNA with a thermostable DNA polymerase. Science 239:487-491

Saiki R, Scharf S, Faloona F, Mullis K, Horn G, Erlich H, Arnheim N (1985) Enzymatic amplification of beta-globin genomic sequences and restriction site analysis for diagnosis of sickle cell anemia. Science 230:1350-1354

Sanger F, Nicklen S, Coulson AR (1977) DNA sequencing with chain-terminating inhibitors. Proceedings of the National Academy of Sciences 74:5463-5467

Shimomura O, Johnson FH, Saiga Y (1962) Extraction, purification and properties of aequorin, a bioluminescent protein from the luminous Hydromedusan, Aequorea. J Cell Comp Physiol 59:223-239

Silverman SK (2003) Rube Goldberg goes (ribo)nuclear? Molecular switches and sensors made from RNA. RNA 9:377-383

Siomi H, Siomi MC (2009) On the road to reading the RNA-interference code. Nature 457:396404

Skop AR, White JG (1998) The dynactin complex is required for cleavage plane specification in early Caenorbabditis elegans embryos. Curr Biol 8:1110-1117

Smith HO, Welcox K (1970) A restriction enzyme from Hemophilus influenzae: I. Purification and general properties. J Mol Biol 51:379-391 
Smithies O, Gregg R, Boggs S, Koralewski M, Kucherlapati R (1985) Insertion of DNA sequences into the human chromosomal $\beta$-globin locus by homologous recombination. Nature 317:19

Tabery J, Piotrowska M, Darden L (2015) Molecular Biology. http://plato.stanford.edu/archives/sum2015/entries/molecular-biology/. Accessed 13th June 2015

Tabuse Y, Izumi Y, Piano F, Kemphues KJ, Miwa J, Ohno S (1998) Atypical protein kinase C cooperates with PAR-3 to establish embryonic polarity in Caenorbabditis elegans. Development 125:3607-3614

Takahashi K, Tanabe K, Ohnuki M, Narita M, Ichisaka T, Tomoda K, Yamanaka S (2007) Induction of Pluripotent Stem Cells from Adult Human Fibroblasts by Defined Factors. Cell 131:861-872

Takahashi K, Yamanaka S (2006) Induction of pluripotent stem cells from mouse embryonic and adult fibroblast cultures by defined factors. Cell 126:663-676

The C. elegans Sequencing Consortium (1998) Genome Sequence of the Nematode C. elegans: A Platform for Investigating Biology. Science 282:2012-2018

Thomas KR, Capecchi MR (1987) Site-directed mutagenesis by gene targeting in mouse embryoderived stem cells. Cell 51:503-512

Timmons L, Fire A (1998) Specific interference by ingested dsRNA. Nature 395:854-854

Trujillo CM, Anderson TR, Pelaez NJ (2015) A Model of How Different Biology Experts Explain Molecular and Cellular Mechanisms. CBE Life Sciences Education 14:ar20

van der Krol AR, Mur LA, Beld M, Mol JN, Stuitje AR (1990) Flavonoid genes in petunia: addition of a limited number of gene copies may lead to a suppression of gene expression. The Plant Cell 2:291-299

van Rij RP, Andino R (2006) The silent treatment: RNAi as a defense against virus infection in mammals. Trends Biotechnol 24:186-193

Vaucheret H et al. (1998) Transgene-induced gene silencing in plants. The Plant Journal 16:651659

Vogel T, Gluzman Y, Winocour E (1977) Recombination Between Endogenous and Exogenous Simian Virus 40 Genes: II. Biochemical Evidence for Genetic Exchange. J Virol 24:541550

Waterhouse PM, Graham MW, Wang M-B (1998) Virus resistance and gene silencing in plants can be induced by simultaneous expression of sense and antisense RNA. Proceedings of the National Academy of Sciences 95:13959-13964

Waterhouse PM, Wang M-B, Lough T (2001) Gene silencing as an adaptive defence against viruses. Nature 411:834-842

Waters CK (2007) Causes that make a difference. J Philos 104:551-579

Watson JD, Crick FH (1953) The structure of DNA. Cold Spring Harb Symp Quant Biol 18:123-131

Weber M (forthcoming) Causal selection vs causal parity in biology: relevant counterfactuals and biologically normal interventions. In: Travisano CKWM, Woodward J (eds) Philosophical Perspectives on Causal Reasoning in

Biology. University of Minnesota

Press, Minneapolis,

Wightman B, Ha I, Ruvkun G (1993) Posttranscriptional regulation of the heterochronic gene lin-14 by lin-4 mediates temporal pattern formation in C. elegans. Cell 75:855-862

Woodward J (2010) Causation in biology: stability, specificity, and the choice of levels of explanation. Biol Philos 25:287-318

Wright Addison V, Nuñez James K, Doudna Jennifer A (2016) Biology and Applications of CRISPR Systems: Harnessing Nature's Toolbox for Genome Engineering. Cell 164:29-44 
Zamore PD, Tuschl T, Sharp PA, Bartel DP (2000) RNAi: double-stranded RNA directs the ATP-dependent cleavage of mRNA at 21 to 23 nucleotide intervals. Cell 101:25-33 